\title{
Kamusal Alan Kavramı Çerçevesinde Türkiye'de 68 ve 80'lerdeki Öğrenci Hareketleri Üzerine Yeniden Düşünmek
}

\author{
DOI: $10.26466 /$ opus.604812
}

\author{
* \\ Gamze Aksan* \\ * Dr. Öğr.Üyesi Selçuk Üniversitesi, Edebiyat Fakültesi, Sosyoloji Bölümü Konya /Türkiye \\ E-Posta: gaksan@selcuk.edu.tr \\ ORCID: 0000-0001-5051-4630
}

\section{Öz}

Bu çalışmada Türkiye'de kamusal alan konusundaki teorik ve pratik tartışmalar göz önünde bulundurularak öğrenci hareketleri farklı bir kamusal alan kurgusu ile analiz edilmeye çalışılmıştır. 60'lı ve 80'li yıllardaki öğrenci hareketleri merkeze alınarak kamusal alan tartışmaları çerçevesinde değerlendirilmiştir. Kavramla ilgili tarihsel arka plan ve temel teorik yaklaşımlar, geleneği bozmadan Locke, Mill, Rawls, Hayek gibi liberal düşünürlerin görüşleri ile birlikte Habermas, Arendt ve Sennett'in kuramsal çerçevesi ve Negt, Kluge'nin tartışmalara teorik katkısı üzerinden ele alınmıştır. Burada bahsedilen yıllardaki öğrenci hareketleri, daha eleştirel ve muhalif olarak formüle edilmiş olan "karşıt kamusal alan" yaklaşımı çerçevesinde değerlendirilmiş, tarihsellik göz önünde bulundurularak doksanlı yıllardaki öğrenci hareketlrine temel noktalar açısından değinilmiştir. Elde edilen bilgiler ve yapılmış çalışma bulguları 68 kuşağının sonraki ö̆grenci hareketlerine kıyasla toplumsal, siyasal ve kültürel açıdan çok daha farklı ve etkili dinamiklere sahip olduğunu göstermektedir. Ancak söz konusu gençlik hareketlerini keskin kıyaslarla değerlendirmenin ötesinde, kendi etkileşim alanların anlamlandırmak, bu hareketlerin mevcut potansiyellerinin tarihsel açıdan günümüze uzanan bağlantılarımı açı̆̆a çıkarması bakımından önem taşır.

Anahtar Kelimeler: Kamusal Alan, Öğrenci hareketleri, 68 ve 80 Kuşă̆ı 


\title{
Rethink The Framework of The Public Sphere on The Student Movement in 68 and 80 in Turkey
}

*

\begin{abstract}
In this study, theoretical and practical discussions about student movements, considering the public sphere in Turkey is to analyze the public domain with a different plot. Student movements in the 60s and 80s were taken into the center and evaluated within the framework of public sphere discussions. The historical background of the concept and the basic theoretical approaches are handled through the theoretical framework of Habermas, Arendt and Sennett and Negt, Kluge's theoretical contribution to the discussions, together with the views of liberal thinkers such as Locke, Mill, Rawls, Hayek, without breaking the tradition. The student movements in the years mentioned here have been evaluated within the framework of the "opposing public sphere" approach, which has been formulated as more critical and oppositional. The subject is historically linked to student movements in the 90s. The information obtained shows that 68 generations have very different and effective dynamics in social, political and cultural aspects compared to subsequent student movements. However, beyond evaluating these youth movements with sharp comparisons, it is important to make sense of their own areas of interaction in terms of revealing the historical connections of these movements to their present potential.
\end{abstract}

Keywords: Public sphere, Student movement, 68 and 80 Generation 


\section{Giriş}

Sosyal bilimlerde genellikle sivil toplum ile paralellik kurularak analiz edilen kamu, kamusal, kamusal alan kavramları farklı tartışma zeminlerinde yer bulan önemli anahtar kavramlardır. İlgili yazın değerlendirildiğinde, ülkemizde 90'lı yıllarla beraber kavramın ve bu çerçevedeki tartışmaların önem kazanmaya başladığı görülmektedir. Özellikle 90'l1 yıllarda sosyal bilimlerin bu kavramlar ile ilgilenmesinin en önemli nedenlerinden birisi sosyal hareketlerle birlikte örgütlü hale gelmeye başlayan farklılık arayışları ve eleştirel tavır olurken, diğer bir yandan söz konusu "farklılıkları bir arada barındıracak ortak alanın tanımı nasıl yapılmalıdır?" sorusu, kamusal alan tartışmalarının merkezinde yer almaktadır. Bu tartışmaları önemli kılan temel vurgu ise gerçekte sivilleşme ve demokrasi ile yakından ilgilidir. Çünkü demokrasinin "öteki ile ilişki" ve bu ilişkinin gerçekleşebilme düzeylerine verdiği cevap kamusal alanda varlık bulmaktadır.

Demokrasi olgusunun belirleyici rol oynadığı kamusal alan tartışmalarında diğer bir önemli nokta ise bu "ortak alan" da, "ortak belirlemelerimiz" sonucu herkesin uyması gereken "ortak kurallar" konusundadır. Sorun ise burada bahsedilen "herkes" in (nesneye dönük olarak) "ne" olduğu ve kuralların kimler tarafından, nasıl ortaya konulduğu ile ilgilidir. Tarihsel gelişim süreci değerlendirildiğinde bütüne ait olma, bütünü kapsama iddiasında olan kamusal alanın belirli güç odakları ve ilişkileri nedeniyle zaman zaman kendi tanımını aştığı görülmektedir. Bu sebeple, kavramdaki bütünlük atfı belirsizleşmekte, kamusal alan tartışmalarına dair teorik ve pratik analizlerin yapılması güçleşmektedir. Diğer bir sorun farklı coğrafi ve kültürel arka planlarla ilgilidir. Örneğin Türkiye'de kamusal alan denildiğinde bu, ortak bir alanı ya da burjuva alanını çoğunlukla çağrıştırmaz. Son yıllarda kavram, her ne kadar bu bağlamından siyrılma ivmesini arttırsa da, "devlete ait olma" ya da "devletle karakterize olma", halen gündelik hayatta "kamusal"ın genel algısını ifade eder. Bahsedilen bu "kamusal alan' algisı, sivil toplum konusunda da devleti baskın unsur addederek yanıltıcı olur. Ayrıca bu yönde bakış açısı, örneğin öğrenci hareketleri ya da farklı kamusal meselelerde, kamusal alanın kavramsal ve kuramsal açıdan tartışmalara sağlayacağı analitik 
katkıyı devre dışı bırakabilir. Kamusal alan kavramı her şeyden önce soyut bir analiz nesnesi olarak; demokrasi, devlet, sivil toplum gibi siyasetin nüvesindeki temel olguları anlamaya ve açıklamaya yardımcı olmaktadır. Gerçekte tüm bahsettiğimiz bu kavramların siyasetin ötesinde, sosyal ve kültürel alanlarla etkileşimi neredeyse varlık sebepleridir. Örneğin sivil toplumun kamusalla ilişkisi, tam da bu noktada birey ile devlet arasında aracı konumu ile kendisini gösterirken amacına uygun bir işleyiş için, tüm bunların içerisinde var olduğu ve ilişki kurduğu bu alanın bazı özelliklerinin olması beklenir. Kamusal alanın bireylerin öteki ile kurduğu ilişkide sağladığı zemin, dolayısıyla da demokratik ya da açık bir kamusal alan; aslında güçlü bir sivil toplum için de zorunlu önkoşul olarak görülmektedir. Dolayısıyla bu konuda yapılacak olan farklı analizler kamusal alan ve onunla etkileşim halinde olan tüm diğer kavramların tartışma zeminini genişleterek toplumsal faydaya dönük kapasitesini ortaya çıkarır. Türkiye'de öğrenci hareketleri konusunun kamusal alan ekseni ise; var olan söylemlere alternatif üreten, dönemin ruhunu taşımakla beraber kendi özel sorunlarını da gündeme getiren, ayrıca birden fazla nesil üzerinden politik söylem alanını ve bu konudaki değerler aktarımını etkileyen önemli bir karşıt kamusallık örneğidir. Özellikle Türkiye açısından, 1968' de ilk boykot hareketinin başlamasıyla aslında öncekilerden farklı bir kamusallık ortaya çıkmış, 68 öğrenci hareketleri bir bakıma cesaretin nişanesi olarak sonraki süreçleri; 70 ve 80 'lerdeki ardıllarını; diğer taraftan 90'lı yılların ve 2000'lerin öğrenci hareketlerini etkileyen olayla yaşanmıştır. Bu çalışmanın temel odağı kamusal alan tartışması ekseninde Türkiye'deki öğrenci hareketlerini 60 ve 80'li yıllar bazında değerlendirmektir. Çalışma, nitelik ve nicelik olarak, 90’lar ve sonrası öğrenci hareketlerini kapsayacak biçimde geniş bir çerçevede konuyu ele almayı amaçlamasa da, tarihsellik açısından özellikle 90'l1 yılların temel özellikleri vurgulanarak sonraki örneklerini de ilgilendiren bazı konular tartışmaya açılacaktır. Çalışmada ilk olarak kamusal alanla ilgili başlıca kavramlar ve süreçler değerlendirilerek; konu ile ilgili temel teorik yaklaşımlara değinilecektir. Daha sonra o yıllarda gerçekleştirilen bazı çalışmalar ve birtakım yorumlar üzerinden hareketlerin temel motivasyonları anlamlandırılmaya çalışılacaktır. Sonuçta, "68 hareketlerinden mit 
ve gerçek olarak bugüne ne kaldı?" sorusu merkezinde pratikler ele alınarak günümüzde üniversite gençliği üzerine bazı söylemlerin kısa bir değerlendirmesi yapılacaktır.

\section{Kamu, Kamusal, Kamusal Alan: Kavram ve Tarihsel Arka Plan}

Türk Dil Kurumu kamusal kelimesini “kamu ile ilgili” şeklinde tanımlamaktadır. Ayn sözlük kamu kelimesine ilk olarak; "halk hizmeti gören devlet organlarının tümü", ikincisi; "bir ülkedeki halkın bütünü, halk, amme", üçüncü anlam olarak ise "hep, bütün" karşılığını vermektedir. Kamusal alan ise "kamuya ait, kamu ile ilgili işlerin yapıldığı yer" olarak tanımlanmaktadır ${ }^{1}$. Kavramın farklı dillerdeki anlamlarına bakıldığında, örneğin İngilizcedeki "public" kelimesinin etimolojik kökeni 14. Yüzyıl'a dayanırken o günkü anlamı ile "umumun gözetimine, bilgisine açık" demektir. Zaman içerisinde kelime "bütün herkesi ilgilendiren" anlamında kullanılmıştır. Latince köken ise "pablicus", halkın hepsini ilgilendiren demektir (Back, 2005, s.11). Almancada ise "kamu" kavramı kendisinden daha eski olan "kamusallık" kelimesinden türetilmiştir (Habermas, 2007).

Kamusal alan konusundaki teorik analizlerde modern zamanlarla birlikte, modern ulus devletin kamusal alanı kapladığı fikrine sıkça rastlanılmaktadır. Gerçekte "kamu" nun devlet işleri ve devlet otoritesi ile eşdeğer görülmesinde bu fikrin etkili olduğu düşünülmektedir. Bununla ilişkili olarak, devletin küçültülmesi, kamusal alanda etkinliğinin sınırlandırılması ve toplumsal etkinliklere yani sivil topluma daha çok yer açılmasına vurgu yapılmaktadır (Yelken, 1999, s.181; 2003, s.46). Ayrıca bireysel hak ve özgürlükler, farklılık talepleri ve çok kültürlülüğü içeren toplumsal bir dokuya yapilan vurgu, sivil toplum ve kamusal alan dolayımıyla yeni bir demokrasi; kısacası yeni bir siyaset arayışı üretme çabasındadır. Bu bağlamda hem sivil toplum hem de kamusal alan, siyasetin altında onu besleyen bir alan olarak dinamik rol oynamaktadır (Yildız, 2005, s.43).

${ }^{1}$ http://www.tdk.gov.tr/index..php?option=com gts\&a ama=gts\&guid=TDK.GTS.5c7e6d38d48107.65$\underline{178800}$ (erişim: 5.3.2018) 
Batı kaynaklı bu kavramın tarihsel kökenleri de ister istemez aynı coğrafyadaki etkileşim süreçleri açısından değerlendirilmektedir. Bu çerçevede öncelikle Yunan şehir devletlerinde özgür vatandaşların ortak alanları ile tek tek şahıslara ait alanın birbirinden kesin olarak ayrıldı ̆̆ı göze çarpar. Siyasal düzeni patrimonyal köle iktisadına dayanan antik Yunanda kamusal hayat çarşıda (agora) cereyan etmektedir. Kamusal hayata katılmanın ön koşulu ise bir aile reisi olarak özel alanda özerk olmaktır. Özel alan ise Yunancada adı itibariyle (oikos) eve bağlı olurken yoksulluk veya köleden yoksunluk başlı başına polise katılmanın önünde engeldir (Habermas, 2007, s.59-61). Avrupa ortaçağında durum farklılaşır; ortak kullanıma açık yerler kamusaldır. Fakat burada "umumiler" karşısında "hususiler" de varlığını sürdürmektedir. Yine de Habermas'a göre bu ortaçağ feodal toplumunda sosyolojik anlamda, yani kurumsal ölçütlere dayanarak, özel alandan ayrışmış kendi başına bir kamu alanından söz edilemez. Bireyselleşmiş ahbaplık zemininin nezih bir muhite dönüşmesi ancak erken kapitalist dönem temelinde, ulusal ve bölgesel devletlerin oluşması ve feodalitenin temellerinin sarsılmasıyla mümkün olabilmiştir. Habermas'a göre özgül ve modern anlamiyla özel ve kamusal alan ancak o zaman ayrışmaya başlar. Bu bağlamda "özel", devlet alanı dışında olmaktır, çünkü "kamusal” bu arada mülkiyetçilikle birlikte, egemen olanın şahsından bağımsızlaşarak nesneleşmekte olan devlete ilişkili hale gelir (Habermas, 2007, s.71-72). 18. yüzyıla gelindiğinde ise Sennett' e (1996, s.35) göre şehir yaşamının beraberinde getirdiği kamusal ve özel yaşam arası ortaya çıkan farklılaşmada medeni talepler ile doğal talepler arasındaki gerilim yalnızca çağın yüksek kültürüne nüfuz etmekle kalmaz, bu durum sıradan yaşam alanlarına da yayılır. Kamusal-özel ayrımı çocuk yetiştirmeye ilişkin kılavuzlarda, ahlaki yükümlülükler üzerine yazılmış eserlerde ve kamuoyunun insan haklarına ilişkin inançlarında ortaya çıkarak artık toplumsal ilişkiler evreni diye adlandırabileceğimiz şeyi oluşturur. Habermas (2007, s.71,72) bu yüzyılın sonuna dek ayakta kalan temsili kamu örnekleri olan prensler, feodal erkler ve kilisenin kutuplaşma sürecinden sonra bir yanda özel diğer yanda kamusal unsurlar kalacak şekilde parçalandığını ifade eder. Bu parçalanma sonucu din özel alana çekilirken kilise varlığını herhangi bir kamu hukuku kurumu olarak sürdürür. Bürokrasi ve ordu, kısmen de yargı ile kamu erkinin kurumları, sarayın adım adım özelleştirilen alanı 
karşısında nesnelleşir. Mesleki zümreler de bu ayrışma sonucu, özel özerkliğin esas alanı olarak devletin karşısında yer alacak olan "burjuva toplumu"nun alanına dönüşür. Bu anlamda kamusal-özel ayrımı, artık kamusal (ortak) çıkarlara duyarlı yurttaşlar toplumu ile kendi özel çıkarlarını gözeten burjuva toplumu arasındaki ayrımdır. Sivil toplum ile devlet arasındaki ayırım ise burjuva kamusal alanının zemini olurken özel alan haline gelmiş toplum, devlete karşı bir konumdaymış gibi görünür (Sarıbay, 2000, s.4).

19. yüzyıla gelindiğinde burjuva toplumunun yapısal olarak özel alanı içine gizlenen özel mülkiyet ilişkileri ve patriarkal aile alanlarındaki çelişkiler, toplumun bütününü ilgilendiren temel sorunlar olarak açığa çıkmaya başlar (Özbek, 2004, s.51). Habermas'ın kendi tanımına baktığımızda ise kendisinin de kamusal alanı özel şahısların kamusal meseleleri ve ortak çıkarları tartışmak üzere bir araya geldikleri bir alan olarak görmesi söz konusudur. Bununla ilgili olarak, konuşmalar aracılığıyla politik katılımın canlandırıldığı bir tiyatro benzetmesi yapar. Böyle bir alanda ise yurttaşlar, müşterek meselelerine dair düşüncelerini açıklar ve böylece söylemsel bir etkileşimde bulunurlar. Bu alan devletten ayrı olmakla birlikte aslında devletin kritik edildiği söylemlerin üretilip dolaştığ alandır (Sarıbay, 2000, s.4).

Kamusal alanla ilgili daha güncel analizlerde özellikle kavramın teorik çerçevesi tartışma zemini açısından Habermas ve Arendt'in kamusal alan modellerini öne çıkarmaktadır. Ancak konu ile ilgili liberal ve proleter yaklaşımlar kamusal alan kavramının farklı yönlerini görebilmemizi sağlıyor. Burada özellikle 20. Yüzyılın sosyolojik koşulları ile birlikte değişen bakış açılarını göz önünde bulundurmamız gerekir. Artık "kamu"nun devletin alanına mal edilmesi üzerinden gerçekleşen tartışmaların ötesinde, üretim ilişkilerinin belirleyici olması ve örneğin cinsiyet tartışmalarını da kapsayarak bir takım iktidar odaklarının merkezileşmesi, kamusal alanı organize etme ve yönetmede güç sahibi olması gibi, mikro analizlerle de çeşitlilik kazanan kamusal alan tartışmaları günümüzde daha farklı sorunlara cevap arıyor. Bu alan eskisi gibi homojen bir içeriğe de sahip değil, mobilite, diğer taraftan göç ve savaşların bu sürece etkisi ile kamusal alan tartışmalarında farklılıklar konusu çok daha önemli bir hale geldi. Diğer taraftan sanal kamusallık gibi yeni tartışmalarla, kamusal alan için değişen mecraların kritize edildiğini görüyoruz. Bu 
çalışmanın özel ilgisi ise; öğrenci hareketlerinde 68 ve 80 sürecidir. 90 sonrası ise başlangıçta daha dinamik kamusallık örnekleri ile başlayan, sonrasında, 28 Şubat, kat sayı mağduriyeti gibi süreçlerle sekteye uğrayan önemli olayların yaşandığı bir dönemdir. Bu süreç her ne kadar politik düzeyde 2000'li yıllardaki benzerlerini etkilemiş görünse de bahsedilen y1llar bilgi teknolojilerinin gelişmesi ile birlikte toplumsal değişimin hızla arttığı, bu açıdan küresel farkındalığın da arttı̆̆ı, kuşaklar arası farkların iyice belirginleştiği, yine önemli bir takım toplumsal süreçlerle beslenen önemli olayların yaşandığı bir dönemi aslında günümüze bağlamaktadır. Ancak 90'lardan günümüze kadar olan dönemdeki öğrenci hareketleri daha önce de belirttiğimiz gibi, kendi iç ilişkileri açısından farklı bir çalışmada başlı başına üzerinde durulması gereken bir konudur. Şimdi kamusal alanla ilgili temel kuramsal yaklaşımlara kısa bir göz atalım.

\section{Kamusal alanla ilgili temel yaklaşımlar}

Kamusal alanla ilgili teorik tartışmalarda öne çıkan Locke, Mill, Rawls ve Hayek gibi düşünürler, kamusal alanı, benzer ve farklı yönleri ile ele alarak liberal kamu modeli çerçevesinde ele almışlardır. Liberal görüşlerin birleştiği ortak nokta; devletin, kamusal alanda tarafsız usul kurallarını uygulayarak, onu güvence altına alması zorunluluğudur. Bunun için hukuk devleti ve insan hakları, anayasal-kurumsal güvencelerle korunuyor olmalıdır. Bu; hukuk önünde eşitlik ile sivil ve siyasal özgürlüklerin anayasal olarak tanınmasını gerektirir (Yükselbaba, 2008, s. 234). Dayanılan, tarafsızlık ilkesinin aksi durumunda “(...) devlet ortak çıkara göre değil, bürokratik veya belli bir toplum kesiminin tercihlerine göre işlemeye başlar." (Erdoğan, 2006, s.100). Liberal kamu modelinin klasiklerinden olan Locke ve Mill, kamusal ile özel alan arasında ayırım öngörür. Locke'un “sözleşme kuramı"nın temelinde -yaşamı, özgürlüğü ve mülkiyeti korumak amacıyla- ikili bir ayrım yatar: ilki insanların toplum halinde birleşmelerine yol açan ve insanlar arasında yapılan sözleşmedir. Aslında insanlar bu sözleşme ile toplumu oluşturur. İkincisi ise insanların devletle gerçekleştirdiği ve doğal haklarını kamuya devrettiği sözleşmedir. (Yükselbaba, 2008, s.235). Burada çıkar çatışmaları ve görüş ayrılıkları gözetilerek homojenliğin önemine vurgu yapılır. Homojen ortak bir paydanın kaynaklık edeceği bir önerme olmaksızın 
sözleşmeye işlerlik kazandıracak mekanizmanın kurulması mümkün değildir (Karadağ, 2003, s.180). Locke'a göre sözleşmenin ihlali, hem bireysel hem de kollektif düzeyde direnme hakkı verir (Eroğlu, 2010, s.2). J. Stuart Mill ise sosyal yaşantının sivil ve siyasal boyutunun hoşgörüyü esas alan bir çeşitlilik üzerine inşa edilmesi gerektiğini savunmaktadır. Toplumsal alan, farklı bireyselliklerin karşılıklı etkileşimde bulunduğu bir yerdir. İnsan doğasındaki bu farklılık toplumsal yaşantıya da yansitılarak çeşitlilik ve farklılığa açık bir toplum projesi tesis edilmesi ve bu eksende tarafsız bir devlet gereklidir (Çaha, 2003a, s.49-50). Toplum haline yaşamanın bir gereği olarak, bireylerin toplum içerisinde yaşayan diğer insanlara karşı belirli sorumlulukları vardır. Bu sorumluluk her birey için iki tür yükümlülük getirir. Bunlardan ilki; birer hak olarak kabul edilen menfaatlere, yasal hükümler ya da zımni anlaşmalarla zarar verilmemesidir. Diğer taraftan toplumun ve üyelerinin, zararlardan korunabilmesi için yapılacak çalışma ve fedakârlıklardan her bireyin, payına düşene katlanmasıdır. Birey eylemlerinin sonuçlarından sadece kendisi etkileniyorsa, bu yükümlülüklerin dışında davransa da müdahale edilmemelidir. Siyasal alanın kurulmasını ise iki ilke üzerinden açıklar; ilk olarak en iyi hükümet biçimi değişmez biçimde her türlü uygarlıkta uygulanan bir biçim değil; uygulanabilir ve seçilebilir olduğu koşullarda varlık gösteren, dolayısıyla da büyük nicelikte yararlı sonuçları doğuran bir hükümet biçimidir. İkinci ilke ise, 'her yurttaşın arada sırada, yerel ya da genel bir kamu görevini kişisel olarak yerine getirmek amaciyla hükümette gerçek bir görevi yüklenmeye' çağrılmasıdır(Karadağ, 2003: 180). Dolayısıyla birey aslında hem kamusal alanın kendisini hem de kamusal yararı belirleyen aktif bir unsura dönüşür.

Kamusal alan tartışmalarına önemli bir katkı da liberal kamu alanının sınırlarını belirleyen çağdaş yazarlardan Friedrich A. Hayek tarafından yapılmıştır. Hayek, devletin işlevini ve müdahil olabileceği alanları ele almıştır. Hayek'e göre devletin görevi insanın doğuştan var olan haklarına sahip çıkmaktır. Siyasal iktidar, "kamusal iyi”yi sağlamak niyetinde olmamalıdır: "Siyasal iktidarın görevi kitlelerin ihtiyaçlarını kendilerinin tanımlamasına müdahalede bulunmamak ve bu ihyiyaçlarını sağlayabilecekleri koşulları ortaya çıkarmak olmalıdır. Devletin müdahalesi olabilecek en düşük seviyede olmalı ve bireylere özgürlüklerini gerçekleştirebilecekleri geniş bir özel alan sağlanmalıdır. Hayek'in (1995, 
s.150; 1999, s.131) yaklaşımlarında öne çıkan vurgular ise devlet müdahalesi ve totaliterleşme eğiliminin eleştirisi üzerinden okunabilir. Bu noktada ekonomik yaşama sosyal adalet adına küçük bir müdahale bile toplumu kölelik yoluna sokar, devletin piyasaya müdahalesinin bireylerin kendi kaderlerini gerçekleştirememelerine neden olur ve devletin bireyleri ortak iyi adına kurduğu amaçlar hiyerarşisine tabi kılar. Düşünür devletin gün geçtikçe büyüyerek baskıcı ve totaliter bir yapıya bürüneceğinden kaygı duyarken, onun sivil alandaki sınırları konusunda da fikir verir. Bireylerin özgür seçimler yapmalarının koşullarını sağlamak burada önemlidir. Bireysel özgürlügün, yani özel alanın gerçek ve ideal alanı ise piyasadır. Devlet; bireyin özgürlüğünü koruma görevini piyasaya müdahale etmeme ve piyasanın işlemesi için koşullarını garanti altına alma ile gerçekleştirebilir. (Yükselbaba, 2008, s.238). Liberal kamu alanı fikrinin çağdaşlarından olan John Rawls ise kamusal alanı "başlangıç durumu", "siyasal adalet", "kamusal akıl" ve "örtüşen uzlaşma" kavramları çerçevesinde ele alır. Rawls, siyasal adaletin bir koşulu olarak; demokratik bir ortamda eşitlik, özgürlük haklarından vazgeçmeden farklı öğretilere sahip yurttaşlar olarak bir arada yaşayabilme sorunu üzerinde durur. Burada "genel iyi" olarak kabul edilen bir anlayıştan ziyade farklı iyi anlayışlarının, farklı ve çatışan çıkarların bulunduğu toplumlarda özgür ve eşit yaşantı mümkün olabilir. Kamusal akıl denen şey ise baskıcı ve zorlayıcı yönlere sahiptir. Bu durum kamusal müzakereleri de sınırlar. Fakat bu sınır siyasal adaletin ilkeleri açısından düşünülmelidir. Siyasal adalet üzerinde uzlaşı sağlandıktan sonra kamusal doğrulama açısından hangi ilkelerin makul olduğu konusunda farklı görüşler olabilir. (Karadağ, 2003, s.184).

Kamusal alan tartışmalarına en önemli katkıyı sunan düşünürlerden birisi olan Habermas ise kendi yaklaşımında özetle burjuva kamusal alanını temel almaktadır. Habermas'ın, modeline getirdiği tanımda (2004, s. 95); 'kamusal alan' kavramıyla her şeyden önce, toplumsal yaşamımız içinde, kamuoyuna benzer bir şeyin oluşturulabildiği bir alan kastedilmektedir. Bu alana tüm yurttaşların erişmesi garanti edilir. Özel bireylerin kamusal bir gövde oluşturarak toplandıkları her konuşma, kamusal alanın bir parçası gibi varlık kazanmış olur. Bu tür biraradalık durumundaki bireylerin davranışları, iş ve meslek sahiplerinin özel işlerini görürken yaptıkları davranışların ya da bir devlet bürokrasinin yasal 
sınırlarına tabi anayasal bir düzenin üyelerinin davranışların ikisine de benzemez. Yurttaşlar ancak, genel yarara ilişkin meseleler hakkında kısıtlanmamış bir tarzda, yani toplanma, örgütlenme, kanaatlerini ifade etme ve yayınlama özgürlükleri garantilenmiş olarak tartışabildiklerinde kamusal bir vücutla davranmış olurlar. Dolayısıyla devletin dışında olan bu alan için herkesin erişebilmesi ve bunun güvencelenmesi, katılımın herkese açık olması, katılımda herkesin eşit ve özgür olarak bulunması, gerçekleşen konuşmaların aleni olması, Habermas'ın kamusal alan yaklaşımında ortaya çıkan merkezi öğelerdir. Habermas'ın altını çizdiği modeli Çaha (2003b, s.79) çalışmasında kısaca şu şekilde özetlemiştir: İlkin kamusal alan kavramı genel hatları açısından sanayi toplumunun bir ürünü gibi görünmektedir. Habermas'in deyimiyle bu aslında burjuva toplumunun diğer bir adıdır. İkincisi bu kamusal alan, modernleşme ile kendiliğinden doğup gelişmiş bir alandır, dolayısıyla da inşa edilmemiştir. Üçüncüsü, bu kamusal alan aleniyeti ortaya çıkaran bir alandır. Geleneksel toplumun örttüğü, onun görünmez kıldığı unsurlar, tartışma konuları, değerler, semboller, aktörler, bu alanda alenilik kazanır.

Siyaset bilimci Hannah Arendt'in modelinin temelinde ise Eski Yunan'da karşılaştığımız "polis" vardır. Polis; fiziki konum itibarıyla kent-devlet gibi bir etkileşimde değildir; insanların birlikte eylemde bulunmalarından ve konuşmalarından doğan bir örgütlenmedir. Bir arada yaşayan insanların, başlarına ne gelirse gelsin burada yer aldığ gerçek bir mekândır(Arendt, 2018, s.289- 290). Arendt'in polise önem vermesinin temeli, göz önünde bulundurduğu konuşma ve eylemin eşitlikçi bir ortam ile poliste var olmasında yatar. Polis; haneden yalnızca 'eşitleri' tanıyor olması bakımından ayrılır. Oysa hane tam anlamıyla eşitsizliğin merkezinde yer almaktadır. Burada özgür olmak, yaşamın zorunluluğuna veya başkalarının buyruğuna konu olmak ya da kişinin bizzat kendisinin emir veren pozisyonunda bulunması demek değildi; yönetmek ve yönetilmek anlamlarına da gelmiyordu. Antik [siyasal] eşitlik, kişinin akranlarıyla bir arada yaşaması, "sadece onlarla düşüp kalkması" anlamına geliyordu ve bu düşünce doğal olarak bir kent-devletinde her zaman için nüfusun çoğunluğunu oluşturan 'eşit olmayanlar'ın varlığını önde kabul etmekteydi (Arendt, 2018, s.70- 71). Arendt'e göre(2018, s.108) kamusal alan; eşitlik ve katılımın, bununla birlikte konuşma ve eylemin 
olduğu yerlerde var olur. Konuşma ve eylemi içerisinde barındırmasından dolayı kamusal alan aynı zamanda siyasetin alanıdır. Bu alan, bu alanı oluşturan öznelerin farklılıklarının ortaya çıktığı ve öznelerin farklılıklarıyla var oldukları yerdir. Bundan dolayı, şiddetten arınmıştır. Özel alanla sınırlarını belirleyen de bu şiddetten arınmışlığı ve özgür oluşudur. Şiddet, özel alanda bulunur; özel alan egemenlik ilişkilerinin, kamusal alan ise özgürlüğün ve hiçbir hiyerarşinin bulunmadığı alanlardır. Bu haliyle kamusal alan ile özel alan arasındaki ilişki de mülkiyet esaslıdır. Özel alanda mülkiyet sahibi ve buranın reisi olan kişi kamusal alana katılır. Tüm bunlarla birlikte kamusal alanda bir devamlılık söz konusudur. Herhangi bir nesille sinırlanamaz, nesilleri aşan bir ömre sahiptir. (Onat, 2013, s.27). Arendt(2018), kendi teorik kurgusunda aile yaşamının temsil yeri olarak özel alanı, politik yaşam için kamusal alanı işaret ederek bu iki öğeyi birbirinden ayırır.Özel alanı karakterize eden güçler "emek" ve "işs"tir. Kamusal alanı oluşturanlar ise "özgürlük", "söz" ve "eylemdir".

Kamusal alan ve bu çerçevede kamusal insanın çöküşünü tarihsel süreç açısından sosyolojik çözümlemelerle ele alan Sennett(2010); geç modern dönemde kamusal alanın içinin boşalmasını, bu bağlamda mahremiyete/özele dönüşün nedenlerini sorgulamaktadır. Narsizm ve rehavet, geç modern dönemin kamusallığına ilişkin başlıca iki ilke olurken kamusal davranışın geçirdiği dönüşüm, insanın sosyalliğinin zayıflaması üzerinden açiklanmaktadır(Olgun, 2017, s.50 Bilgir, 2015, s.270). Sennet çalışmasında(2010, s.16); günümüzde kamusal yaşamın formel bir yükümlülüğe dönüştüğünü, çoğu yurttaşın devletle ilişkilerine teslimiyetçi ve kanıksayıcı bir ruh haliyle baktığını açıç̧a ifade eder. Ancak kamusal alanın bu yönde zayıflaması politik faaliyetlerin ötesinde çok geniş bir alanı ilgilendirir. Çünkü bu zayıflama sonucunda yabancılarla kurulan ritüel ilişkiler ve onlara karşı takınılan tavır, en iyimser bakıldığında "formel ve yavan", en kötümser anlamda ise "sahte" görünmektedir. Burada res publica; genel olarak aralarında aile bağı ya da yakın bağlar olmayan insanlar arasındaki birliktelik ve karşılıklı taahhüt bağlarını temsil eden; arkadaşlık ya da aile bağlarından çok bir kitleye, bir halka, bir politik uygulamaya ilişkin bağdır. Ancak günümüzde res publicaya katılım, bir oluruna bırakma sorunudur ve bu kamusal yaşamın şehir gibi mekânları da bozulma sürecine girmiştir. Kamusal alanlar artık 
ortak konu ya da sorunların tartışıldığı tanımından uzaklaşmış, insanların ancak geçip gittiği, bazen de yollarının kesiştiği ortak mekânlara, yerlere(alışveriş merkezleri gibi) dönüşmüştür.

Farklı bir kamusal alan tartışması ise karşıtlık ilişkisi üzerinden inşa edilmiştir. Karşıt bir kamusal alan modeli olan, Oskar Negt ve Alexander Kluge'nin ortaya koyduğu "proleter kamusal alan", Habermas'ın söylemsel kamusal alan modelini temeline oturtarak ve modeli birçok yönden eleştirerek geliştirmiştir. Proleter kamusal alan modeli, esasında kamusal alanı üretim ilişkileri üzerinden tanımladığı gibi proletaryayı kamusala taşımaya ve egemen kamusal alanı ele geçirmeye yöneliktir. Sınıflar üzerinden toplumu tarif etmesi; diğer modellerin tümünün liberal olması ve liberalizmin meşruiyet krizini çözmeye yönelmesi gibi sebeplerle diğer yaklaşımlardan ayrılır (Yükselbaba, 2008, s.258). Hansen'in deyişiyle (2015, s.175- 176); Negt ve Kluge'un(1972/2018); görüşüne göre kamusal alan; bir alan olmaktan daha çok, bir süreçtir ve bu alandaki değişim imkânı farklı kamusallık tipleri içine yazılmış olan farklı zamansal işaretlere dayanır. Birbiriyle eşit olmayan örgütsel kamusallık yapılarının aynı yerde yaşaması, rastgele çarpışmalar ve fırsatlar, öngörülemeyen konjonktürler ve şansa bağlı gelişmeleri mümkün kılacak bir değişkenlik ya da kararsızlık potansiyeli içerir. Bu koşullar altında alternatif oluşumlar ve farklı kolektif çıkarlar kendilerine ait bir moment kazanabilir. Asında Habermas, modeliyle "tek ve homojen" bir kamusal alan sunarken esasında burjuva kamusal alanın ortaya çıktığı süreçte çeşitli kamular, "madun karşı kamular" da belirmekteydi. Burada bağımlı toplumsal grup üyelerinin kendi kimlik, çıkar ve ihtiyaçları hakkında muhalif yorumlar formüle etmelerine izin veren karşıt söylemler türeterek yaydıkları, birbirlerine paralel söylemsel alanlara işaret ettiği için, madun, karşıt kamular olarak adlandırma önerilmiştir(Fraser, 2015, s.117). Böylece Negt ve Kluge, Habermas'in kamusal alan anlayışına alternatif bir görüş geliştirmiş ve Habermas'ı bu hali hazırda gelişmekte olan çeşitli kamuları görmezden gelmekle eleştirmişlerdir. Dolayısıyla kamusal alan tartışmaları sınırları bugün biraz daha genişleyerek siyasetin ve siyasal iktidarın kamusal alandaki yetki ve sınırları tartışması ya da tipik kamusallık modellerinin ötesinde; farklı, eleştirel ya da karşıt kamusallıklar üzerinden tartışılmaktadır. Kamusal alan kavramı siyaset, özel olarak da devlet ve toplum ilişkisinde arada kalan alanın, dolayısıyla da toplumsal ilişkiler 
alanının nasıl olması gerektiği konusunda, iktidar biçimleri ile karşılıklı etkileşimde olarak "toplumsal düzen en ideal düzeyde nasıl sağlanır?" sorusuna aranan cevaplarda işleyen anahtar bir kavramdır. Bu çerçevede tartışma zemini geliştiren her bakış açısı, ya da konunun eleştirel tarafları konu ile ilgili analitik yorumları güçlendirir.

\section{Türkiye'de Kamusal Alan Bilmecesi: Yansımalar ve Yanılsamalar}

Kamusal alan kavramı Türkçedeki tanımı itibariyle en genel anlamda "hepe ve bütüne ait olma" iddiası taşımaktadır. Yine kavram "halkın bütününe ait olma" ve "aleniyet"i de içerir. Aslında Türkçe sözlüklerde bu terimin birçok tanımı bulunsa da kamusallık ilkesi açısından, aleniyetin dilimizi ve genel politik kültürümüzü etkileyerek toplumsal geçerlilik kazandığını kolayca söyleyebilmek mümkün değildir. Kamusal olup olmayan genellikle devlet tarafından belirlendiği, daha çok resmi organlar tarafından kullanıldığı için belki de hep devlet kontrolünde ve devlete ait bir alan olarak zihinlerimizde karşıllık bulmuştur. Bir taraftan aslında kamuoyunun halka ait bir fikir olduğu, kamu borcunun halkın tümünün borcu olduğu, kamu hizmetinin devlete hizmet olmadığı bilinirken yine de "kamuoyu"ndaki kamunun kim olduğu düşünülmeden, kamuyu devlet aygıtı ile birleştirerek, tabiri caizse kavram ortadan bölünüp esası kaçırılarak kullanılmaktadır(Özbek, 2004, s.51). Şüphesiz bu algı, belirli tarihsel bir gerçekliğe dayanır. Bu noktada kamusal alan kavramının öznesine ilişkin açıklama yapmakta yarar var. Kamusal alan algımız, kavramın öznesinden yani "kamusal alan" daki "kamu" ile ilişkide belirleniyor. Bu durumu etkileyen süreçlerden örneğin, belki de öznenin devletle ilişkisi; kökenlerini Osmanlı toplumsal yapısının iç dinamiklerinde bulabileceğimiz, devletin araçsal değil aşkın bir varlık olarak görülmesinin etkilerini hatırlatıyor. Cumhuriyetin kuruluş süreci, savaşlar ve sonrası düşünüldüğünde de uzun yıllar devletçi politikaların süreci beslediği açıktır. Ancak toplumdaki devlet algısının baskın karakterinden ziyade kurumsal bazda sivil inisiyatifleri ele alacak olursak, Osmanlı Devleti'ndeki toplumsal kesimlerin devlete bağımlı ve devleti önceleyen bir yaklaşım sergilemelerine rağmen sivil topluma zengin bir dayanak oluşturdukları, yani kamusallık anlamında toplumda sivil in- 
isiyatiflerin bulunduğu söylenebilir. Bu açıdan değerlendirildiğinde Osmanlı toplumunda çok boyutlu bir kamusallıktan bahsedilebilir, çünkü loncalar gibi belirli birimlerin yanı sıra oluşumu devlet dişında yer alan, farklı etnisitelerin ürettiği cemaat, tarikat gibi unsurlar da Osmanlı Devleti'nde varlık imkânı bulabilmiştir (Erol, 2003, s.59). Özellikle de II. Meşrutiyet döneminin yarattığı özgürlük ortamının getirisiyle farklı amaçlarla hareket eden sosyal unsurların yoğunlaştı̆̆ 1 farklılaşmış bir kamusallığ1 net bir biçimde görmek mümkündür. Fakat az önce de ifade edildiği gibi, cumhuriyet dönemi geçiş sürecinde, savaştan çıkmış bir toplum olmanın getirdiği tüm etkilerle birlikte, daha çok tek boyutlu bir kamusallık varlık kazanmıştır. Süreç içerisinde devlet eliyle oluşturulan ve desteklenen bazı birimler, öncesinin kendiliğinden oluşan alanlarından oldukça farklıdır. Cumhuriyet döneminde devlet tarafından ara ara kamusallıklar daraltılmış ve tekçi bir kamusallık inşasına doğru gidilmiştir. Bu daralmanın 30'lu yıllarda doruğa ulaştığı söylenebilir (Bkz. Çaha, 1998, s.88; 2003a; Erol, 2003, s.60). Örneğin "Batılılaşma" fikri paralelinde kadınlara önceleri birçok hak tanınmış ve devletin desteği ile birçok dernek kurulmuştur. Ancak 1935'e gelindiğinde, bütün aracı sivil toplum kuruluşları ve alternatif medya örüntülerinin yasaklanmasıyla bu tarihten itibaren kadınlar, devlet elitleri tarafından kendilerine verilen misyonları yüklenerek yeni rejime hizmet etmek durumunda kalmışlardır. Misyonları ise "cinsiyetsiz vatandaşlar" olmak ve "milleti eğitmek" olarak belirlenmişti. Bu da aslıda kadınların kamusal alanda cinsiyet kimlikleri ile değil, sadece ulus devletin vatandaşları olarak yer almaları demekti (Çaha, 2006, s.8). Bu çerçevede devletçi politikaların kamusalı dönüştürmedeki etkisinin sonuçlarına ulaşıyoruz. Köklü toplumsal değişim ve dönüşüm yaşayan diğer toplumlarda olduğu gibi Türkiye'de de uluslaşma sürecinde yeni toplumun inşası ve bu toplumun gereksinimlerine ve değerlerine uygun yeni insanı yetiştirmek için özelikle de eğitime çok boyutlu roller biçilmiştir (Eskicumalı, 2003, s.22). Batı kaynaklı yenilikler ile toplumun yeniden inşa sürecinde, aslında kendi iç dinamikleri ile oluşması gereken ve beklenen belirli kurumlar; dernekler, basın, edebi ve bilimsel eğilimler, sanatsal faaliyetler, hatta kamuoyu bile devlet tarafından üretilmiş, gerekli görüldügüunde de (ya da görülmediğinde) varlıkları yine devlet tarafından son bulmuştur. Oysa siyasal bir rejim olarak cumhuriyetin kendi dinamiklerini 
incelediğimizde; özel çıkarları ve talepleri bastırmadan, onların varlığına rağmen "ortak iyi" nin nasıl tesis edileceği ile ilgili cevabın klasik cumhuriyetçi anlayışta tanımlandığ görülmektedir. Devlet, kolektif aklı temsil eden bir organ olarak toplum bireylerini kendi özel durumlarına halel getirmeden ortak iyi etrafında toplama görevini yapmakla yükümlüdür. $\mathrm{Bu}$ özelliği itibariyle yani ortak birliği temsil etmesi dolayısıyla herkese açıktır ve kamusal mahiyet arz eder (Sarıbay, 2000, s.18). Ayrıca cumhuriyet rejimi her şeyden önce kamu yararını ön planda tutar ve buna dayanır, kuvvetini de geniş halk kitlesinden, millet iradesinden alan bir yapı sunar (Kocatürk, 1999, s.6). Sarıbay'a göre(2000, s.18-21); Türkiye özelinde söz konusu siyasal rejimin uygulanış pratiği ise kendisini kamusal alanda, farklılıkları ve çoğullukları örter şekilde kolonize etmiştir. Devletin kendisinin moral ve organik bir varlık olarak algılanması, cemiyet ile özdeş görünmesi problemini beraberinde getirir ve tüm bunların sonucu olarak da farklılığı ve bireyselliği teşvik eden bir kültür inşası kısıtlanmış olur. Böylelikle de bizi hem birleştirip hem de ayıran bir kamusaldan ziyade sadece birleştiren bir kamusallık anlayışı yerleşir. Diğer bir taraftan süreç içerisinde laikliğin, devletçi elitler tarafından çok önemli bir sembol olarak kullanılması söz konusudur. Modernleşme deneyimini yaşamaya çalışan Türkiye'de laiklik ile modernitenin farklılaştırıcı işlevi yerine getiriliyor gibi görünse de laiklik, devlet ile toplum arasına bir sınır çizmekten ve farklılıklara eşit mesafede durulmasını telkin etmekten çok devletin toplumu kolonize etmesine, son aşamada ise ikisi arasındaki sınırı silmeye yardımcı olmuştur. Dolayısıyla da kamusalın kendi doğasının bir sonucu olan farklılıkları bir arada tutma iddiasına destek olması beklenen laiklik, yeni bir politik din haline getirilerek kamusal alanın bütünselliğini gerçekleştirmesine aracı kılınmıştır.

Son birkaç on yılda demokrasi taleplerinin artması, beraberinde şüphesiz Türkiye' deki kamusal alanın sorgulanmasını getirmiştir. 80'lerden itibaren yeni toplumsal hareketliliklerin etkisi ile oluşan farklılık arayışları ve bu çerçevede aynı toplumda farklı kalıp bir arada yaşamanın nasıllığına ilişkin cevaplar ile demokrasinin ötekiyle ilişki kurulmasındaki temel argümanları kamusal alanda olup bitene tekabül eder (Göle, 2003, s.89). Dolayısıyla yine söz konusu kavramlarla birlikte, kamusal alan algisına paralel bir şekilde devlete ait atıflarla kurgulanan sivil toplum kavramı da Türkiye'nin gündemine taşınmış ve benzer yıllarda hararetli 
bir biçimde tartışılır hale gelmiştir. Günümüzde bu kavramlar entelektüel karşılıkları açısından devlete daha az rol biçilen, demokrasi düşüncesinde daha az çelişki ile kamusalın toplumun ortak değerler alanı olduğu fikrini daha fazla yücelten bir zeminde ifade edilmektedir. Şimdi ise kamusal alan konusundaki teorik tartışmalardan biraz uzaklaşarak pratik yönlerine değinerek; 1968 ve 1980 yıllarında ortaya çıkan ve önemli etkileşim alanlarına sahip olduğunu düşündügüumüz öğrenci hareketlerini, dönemin Türkiye'sindeki kamusal alan yansıması çerçevesinde mevcut kamusal alandan farklılıkları üzerinden tartışmaya açacağız.

\section{Karşıt Bir Kamusal Alan Olarak Düşünmenin sınırları: Türkiye'deki 1968 ve 1980'lerdeki Öğrenci Hareketleri}

Kamusal alanla ilgili yaklaşımlar içerisinde "karşıt kamusal alan" kurgusu, bu çalışmanın önceki kısımlarında ifade edildiği gibi "proleter kamusal alan" modeli ile Negt ve Kluge (2004, s.139); ekonomi politiğin analitik kavramlarını aşă̆ıya doğru, yani insanların gerçek deneyimlerine indirerek tartışabilecek bir çerçeve sunma amacındadır. Bu amaç, burjuva veya geleneksel akademik kamusal alan biçimleri içerisinde kalarak sürdürülemez. Mevcut toplumsal tecrübeleri yenileriyle bir araya getirecek araştırmaların yapılabilmesi, teorik tartışmaların pratikle örtüşmesi için bu bakış açısını göz önünde bulundurmalıyız. Bu çalışmada karşıt kamusal alan olarak, bahsettiğimiz yıllardaki öğrenci hareketlerini ele alırken proleter kamusal alan bağlamından ziyade mevcut süregiden yapı ve ilişkilere eleştirel karşı çıkış olarak bu hareketin yapısını ve etkileşim alanları üzerine yeniden düşünülmesi amaçlanıyor. Fraser'ın(2015) da ifade ettiği gibi bağımlı toplumsal grup üyelerinin kendi kimlik, çıkar ve ihtiyaçları hakkında muhalif yorumlar formüle etmelerine izin veren karşıt söylemler türeterek yaydıkları, birbirlerine paralel söylemsel alanlara işaret eden tecrübeleri karşıt kamu olarak adlandırmamız mümkün görünüyor.

Bu çerçevede 1960'ların özellikle son yıllarını değerlendirdiğimizde, söz konusu yıllar gerek dünyada gerekse Türkiye'de önemli değişimlerin ve dönüşümlerin yaşandığı, buna paralel olarak farklı kamusallıkların ortaya çıktığı, hak talepleri ve söylemlerin çok daha görünür olmaya başladığı yıllardır. Sanayi kapitalizminin artması, sömürgeleşmenin 
kendisini kültür gibi farklı alanlarda göstermeye başlaması, ekonomik krizler, savaş sonrası buhranlar, pozitif bilimlerdeki ilerlemelerin; bilimin, tekniğin vaat ettiği refah devletinin insanlığın mutluluğunda ve kurtuluşunu sağlamada vaat olarak kalması gibi bir dizi sosyal, kültürel, ekonomik, siyasal süreçlerin yaşandığı bu zaman diliminde söz konusu faktörlerin etkisi ile eğitim alanında özellikle de üniversite öğrencilerinin, farklı çerçevelerde toplumsal sorunlar karşısında belirli bir duruş sergiledikleri görülmektedir. Burada küresel örnekleri açısından; kültürel havzalardaki farklılık söz konusu öğrenci hareketlerinin karakterlerini belirlemiş, benzer gerekçelere sahip olunsa da pratikteki yansımaları değişik biçimlerde ortaya çıkmıştır.

Türkiye'deki pratik öncesinde, aslında belirli bir sürecin sonucu 1968 yılında ortaya çıkan hareketlerin kaynağı olarak batıda meydana gelen öğrenci hareketlerinin temel karakteristiklerine kısaca değinmek gerekirse; örneğin 1968 yılı Fransız öğrenci hareketi, (Fransız devriminde olduğu gibi) farklı açılardan diğer öğrenci hareketlerinin esin kaynağı olarak ayrı bir öneme sahip görülmektedir. Üniversite özerkliği olması, üniversite yönetimine katılım, bursların yükseltilmesi gibi nedenlerle boykotlara başlayan öğrenciler bu tip, kendi eğitimleri ile ilgili taleplerinin yanı sıra siyasi taleplerde de bulunmuştur. Bu hareketin mevcut siyasal rejimi ve toplum düzenini yıkma motivasyonuna sahip, "burjuva üniversitesi" olarak adlandırdıkları üniversiteleri kökten değiştirme amacı güden bir hareket olduğu söylenebilir. Onların düşüncesinde; üniversite kapitalist düzenin yaşayıp güçlenmesine önemli ölçüde yardım etmekte ve sömürüyü hızlandırmaktadır. Toplumun düzeni değişmeden üniversite reformu yapmak anlamsızdır. Toplumun düzenin değişmesinde ise üniversitelerin rolü önemlidir. Aynı yıllarda Fransız öğrenciler "sınıfsız bir toplum kurma mücadelesi" açısından işçilerle de işbirliği içine girmişlerdir. Bu durum, söz konusu Fransız hareketinin diğer ülkelerdeki öğrenci hareketlerinden en önemli farkı olarak karşımıza çıkar (Akyüz, 1969, s.126-129). Almanya'da 1968 yılında başlayan öğrenci hareketleri ise genel olarak devrimci bir yapıdadır. Bu yapı içerisindekiler, üniversitenin kendi iç sorunlarının tüm toplum yapısı ile ilişkilendirilmeden düzelmeyeceği kanaatindedir. Onlara göre Alman toplumu gerçek demokrasiye candan bağlı değildir ve bu, tüm ku- 
rumlarda kendisini göstermektedir. Temel karakteristiğini değerlendirdiğimizde; Alman öğrenci hareketlerinde siyasal nitelik ağır basmakta ancak bunun yanında üniversite yönetimine katılmak, toplumun kuruluşlarını eleştirmek, aksayan sosyal düzeni değiştirmek gibi talepler de bulunmaktadır(San, 1969, s.35-46). Amerika'da ayn yıllarda üniversite öğrencileri, eğitimde ve siyasette söz sahibi olma isteği ile protestoya başlamışlardır. Columbia Üniversitesi'nde başlayan öğrenci hareketinin temel gerekçesi, onların hakkında karar veren mekanizma içinde kendilerinin söz hakkının olmamasıdır. Üniversite işgallerinde ünlü sosyolog Etzione, öğrencileri sükûnete çağırmaya çalışsa da etkili olmamış ve derslere son verilmiştir (Sandıkçıŏlu, 1969, s.145-147). Amerika'daki hareketlerin çerçevesi; nükleer denemelerden kentlerdeki yoksulluk problemlerine, Vietnam savaşına ve askere alınma koşullarına kadar genişlemiştir (Göğüş, 1969, s.153). İtalyan üniversitelerinde ise söz konusu öğrenci hareketleri yine üniversitenin iç imkânları ile ilgili sorunların yanı sıra demokratikleşme ve bağımsızlaşma talepleri ile şekillenmiştir. İtalya'da 1968'deki öğrenci hareketlerini önceki örneklerinden ayıran temel nokta, o zamana kadar olan siyasi parti destekli öğrenci hareketlerinin bu defa siyasi partilerin hepsini reddetmesidir. Üniversiteler yüzyıllar öncesinde özerk kuruluşlar olarak ortaya çıtıkları halde zaman içerisinde devletin organları haline dönüşmüştür. Öğretim planlarının dahi zamanının hükümeti tarafından hazırlanması ve bunun dışına çıkılmasının imkânsızlığı, faşizme bağlılık yemini etmeyen profesörlerin azledilmesi gibi baskılara her ne kadar ikinci dünya savaşı sonrasında tepki gösterilse de, üniversiteler o yıllarda özerk kuruluşlar haline gelememiştir. Bu durum öğrencilerin yanında öğretim üyelerinin de demokratiklik problemi olarak ele aldıkları bir sorundur.(Konanç, 1969, s.100107). Konanç'ın Kasım 1968'de Ankara Üniversitesinde düzenlenen dünyada ve Türkiye'de öğrenci hareketlerini konu eden sempozyumda İtalya' daki durumu şu şekilde ifade etmiş olması önemlidir: "Kanaatimizce İtalya'da en aşırı sağdan en aşırı sola kadar çeşitli eğilimlerde olan öğrencilerin meydanlarda birleşmelerine sebep kendilerinden önceki kuşağm, onlara dokunulmaz olarak gösterdikleri bir takım değerleri, bazı çıkarlar peşinde koşarak, çekinmeden ayaklar altına almalarıdır" (Konanç, 1969, s.114). Sözleri ile eylemleri birbirini tutmayan, toplumun sıkıntıları fark ettikleri halde bunları bertaraf etmek için çaba göstermeyen yetişkinlere karşı; belki de onları 
bertaraf ederek kendi inançları doğrultusunda yeni bir toplum inşa etmek amac1, dönemin öğrenci hareketlerini motive eden önemli bir sebep olarak görünmektedir. Bu durum dönemin siyasi angajmanları ile birlikte okunduğunda; yine dönemin üniversite gençliğinin karşı tavrında politize olmayı reddedişlerini anlamlı hale getirir.

Genel olarak baktı̆̆ımızda öğrenci hareketlerinde benzer dinamiklerle birlikte karışık ve parçalı bir yapı bulunmaktadır. Dünya coğrafyasında önemli bölgelere yayılmış olan eylemlerin (veya hareketlerin) en belirgin ortak noktası eylemi yapanların öğrenci kimliğine sahip olmasıdır Yine de eylemlilikler jeopolitiğin dişına taşarak daha evrensel talepler etrafında birleşme ve mücadele etme çizgisine evrilmişlerdir. Bu çerçevede örneğin Filistin ve Arap ülkelerinde gerçekleşen öğrenci eylemlerinde, yoğun bir anti-emperyalizm ve o coğrafyanın jeopolitik yapısını ilgilendiren sorunlar etkili iken zaman zaman ulusal kurtuluşçu vurgular ifade bulmaktadır. Yine aynı dönemlerde Avrupa'da ortaya çıkan öğrenci hareketleri ise daha çok, sanayi toplumu olgusunun bireylere yüklediği yüksek maliyetli faturaya isyan eder nitelikte talepleri vurguladıkları görülmektedir(Başer, 2001).

Dünyada gerek kapitalist gerek sosyalist ülkelerde meydana gelen öğrenci hareketlerinin birçok eğitimsel sorunlara gebe olan Türkiye'deki örneklerinde kısa zamanda büyüyerek yükseköğrenimi, üniversite çevreleri ve siyasi iktidarı oldukça meşgul ettiği görülmektedir ${ }^{2}$. Sorunlar genel olarak- örneğin, kalabalık sınıflar, yönetmeliklerdeki aksaklıklar, öğretim üyesi-öğrenci ilişkileri zayıflığı, iş bulma zorlukları gibi-diğer ülkelerle benzer özellikler gösterir (Tezcan, 1969, s.169). Fakat bu hareketin kendine özgü yanlarını tekrar hatırlamak önemlidir. Toprak'a göre(2018, s.72) 27 Mayıs öncesinde üniversite gençliği galeyana gelmiş, 28-29 Nisan olayları ${ }^{3}$ farklı bir ivme kazandırmış, siyaset, üniversite ve gençlik iç içe geçmiş sacayaklarına dönüşmüştü. Aynı zamanda iletişim araçlarının etkisi ile dünyadaki benzer hareketler ile ilgili gelişmeler ülke gençliği tarafından yakından izleniyordu. Öncelikle Vietnam savaşı, gençliğin Amerika konusunda politik alana çekilerek karşıt hale gelmesini zirveye ulaştırmıştı.

\footnotetext{
2 Osmanlı ve Cumhuriyet Türkiyesi'nde 1968'lere kadar olan öğrenci eylemleri için ayrıca bkz. Can, T. (1996). Yükseköğretimde öğrenci olayları. Eğitim Yönetimi, 531-538.

${ }^{3}$ Bkz. Temizgüney, F. (2018). 1960 darbesine giden süreçte önemli bir kesit: İstanbul öğrenci olayları. Cumhuriyet Tarihi Araştırmaları Dergisi, 27, 181-211.
} 
Ayrıca hızlı nüfus artışı ve kentsel göç üniversitelere talebi de arttırmış, üniversite kapısında önemli bir birikim oluşmaya başlamıştı. Bu sebeplerle Türkiye'de sinırlı sayıdaki üniversitelerin problemleri gün geçtikçe artarken bu durum üniversiteleri içeriden ve dışarıdan eleştiri odağı haline getirmişti. Üniversite hocalarının bir kısmı bu noktada öğrencilerle ilgili eleştirilere karşı çıkarak durumu şu şekilde ifade etmekteydi: Yolunu şaşırmış gençlik; sırf protesto etmek için nümayiş yapan gençlik; anarşist gençlik; komünist gençlik gibi örneklerinin daha da çoğaltılabileceği adlandırmaların, önyargıdan ileri gitmeyeceği, olayların gerçek nedenlerinin bulunabilmesi bir yana, daha sert karşıt tepkileri davet etmekten başka hiçbir işe yaramayacağı kanısindayız.(San, 1969, s.4)

1968 senesindeki hareketler başlamadan önce, bazı öğrenci gruplarının üniversitede köklü reformlar gerçekleştirmek üzere büyük çapta bir hareket için uzun süredir hazırlanmakta oldukları ve bu zaman dilimini seçtikleri söylenmektedir. İlk boykot hareketi 15 Nisan 1968'de Ankara Üniversitesi İlahiyat Fakültesinde iki öğrencinin disiplin kurulunca fakülteden çıkarılması ile başlamıştır. Öğrenci itirazlarının kabul edilmemesi sonucu fakülte işgal edilir. Boykotçuların istekleri "ilim, tarafsızlık, samimiyet, iman ve vicdan hürriyeti, hakka saygı, aleni ve tarafsız imtihan" dır. İkinci boykot ise tamamen fakültenin kendi iç sorunları ile ilgili olarak Ziraat Fakültesinde çıkar. Ankara D.T.C.F.'nde meydana gelen üçüncü boykotun çıkış nedeni, tekrar öğrencilerin kendi fakülteleriyle ilgilidir. Daha sonra Ankara Hukuk Fakültesi öğrencileri fakülteyi işgal eder ve hareket İstanbul Hukuk Fakültesine, Eskişehir'de ve İzmir' deki fakültelere sıçrar (Tezcan, 1969, s.170-172). Bir taraftan da ABD karşıtı anti-emperyalist protestolar yükselmektedir. Bu protestolarda bir önceki kuşağın Kemalist ve milliyetçi fikirleri ile orduyu ileri bir güç olarak gören darbeci geleneğin etkileri hissedilmektedir. İTÜ Talebe Birliği'nin hazırladığı NATO karşıtı bir afişte 'Mehmetçik heykeli figürü' kullanılması; 68 sonbaharında gerçekleştirilen Mustafa Kemal 
yürüyüşüyle Demirel hükümeti Ata'ya şikâyet edildiğinde, “Bağımsız Türkiye için ikinci kurtuluş savaşı" ifadesinin söylem haline gelmesi, bahsedilen durumun örnekleridir"

Öğrenci boykotlarının temel nedeni ise, eğitimde reformun gerçekleştirilmesidir. Yine de basında öğrenci hareketlerinin siyasi ve ideolojik olduğunu belirten yazılar çıkmış; hareketlerin milletlerarası ve sol karakterli olduğu belirtilmiştir. Ancak boykot hareketi önderleri teşebbüslerinin siyasal ve ideolojik eğilimlerden uzak olduğuyla birlikte herhangi bir eğilime hizmet etmediklerini açıkça ifade etmişlerdir. Bazı parti ve gruplar tarafından yapılan tahrikler de sonuç vermemiştir. Sadece Üniversite Öğrenci Örgütleri Dayanışma Kurulu ve Ankara Yüksek Okullar Talebe Birliği'nin bazı bildirilerinde eğitimi aşan hususlara rastlanmıştır (Tezcan, 1969: 173-175). Bu yılların sadece üniversite konusunda değil, farklı toplumsal alanlar açısından da hareketli olması süreci etkilemiştir. Zira İstanbul, Ankara ve İzmir'de üniversite gençliği, Amerikan 6. Filosuna karşı gösterilerde bulunurken, sağ kadrolar "toplu namazlar" ile karşıt grup oluşturmakta, milliyetçi gençler "komando eğitimi" görürken, komünizmle mücadele dernekleri ise "komünizm telin mitingleri" düzenlemiştir (Çetinkaya, 2002: 11). Başer'e göre(2001); 68'de bütün dünyada kitlesel ve giderek toplumsal bir boyut kazanmış olan hareketlilik, Türkiye'de iktidar karşısında ciddi bir alternatif olamamayla sonuçlanmıştır. Bu durum devletin yoğunlaşan tepkileri ile birlikte dağınıklığın artarak büyümesi, ayrılan parçaların birbirine karşı daha fazla sertleşmesi ile sonuçlanmıştır. Böylelikle hareket, 1971'deki askeri darbeden çok önceleri kısır döngü içine girer. Ancak 12 Mart askeri darbesi, öğrenci hareketlerini önemli bir biçimde etkilemiştir. Öğrencilerin kurduğu örgütler askeri anlamda bastırılırken bunun doğal bir sonucu olarak öğrenci hareketleri, örgütlü gücünden yoksun kalır. Süreç 1974 'te çıkan ve genellikle politik tutsakları kapsayan affa kadar devamlılık gösterir. 12 Mart'ın farklı bir sonucu ise, 68 kuşağının bu dönem zarfında bir sorgulama süreci içine girmesi ve öz eleştiri yapması olarak

${ }^{4}$ http://www.antikapitalist.net/makale/antikap/52 turkiyede-denizler-devrimci-irade-yeterli-mi.htm (erişim tarihi:22.11.2016) 
karşımıza çıkar ve bu bağlamda söz konusu af ile öğrenci hareketleri bazında değişik birtakım yeni oluşumların önü de açılmış olur. 70'li yılların ortalarına gelindiğinde ise Türkiye'deki öğrenci hareketleri eskisinden daha kitleselleşmiş bir biçimde kendisini gösterirken ayn dönemde şekillenen İlerici Gençler Derneği'nin kapitalizm karşısındaki örgütlenme biçimi ve pratiği bu durumun bir örneğidir.

1980 yılı askeri darbe sebebi ile kamusal alanda birtakım oluşumların görünürlüğünü kaybetmek zorunda kaldığı yıldır. Öyle ki, toplumsal hafızada "kardeşi kardeşe düşman eden" ideolojik kamplaşmaların yaşandığı, gençliğin "sağ-sol kavgası" yüzünden birbirini kırdığı, belirli kesimler tarafından askeri darbenin neredeyse "kurtarıcı" olarak çağırıldığı bu dönemle ilgili hatıralar, gençlerin politize olmasını engellemek adına günümüzde dahi söylem olarak gözlemleyebildiğimiz bir etki alanına sahiptir. Lüküslü(2013) bu duruma kendi çalışmasında değinmiştir. Bu yıllarda, önceki tecrübeler üzerinden gençleri adeta tehdit olarak algılayan siyasi iktidarın bu kitlenin denetimini sağlayabilmek amacıyla 1980 yılında Yüksek Öğretim Kurumu'nu kurduğunu, sonrasında da gençleri koruma görevini bizzat devletin üzerine aldığ 1 görülmektedir. Bu noktada 82 Anayasası'ndaki 58. madde, gençler açısından önem taşır. Bu madde ile gençlerin "devletin bölünmez bütünlüğünü ortadan kaldırmayı amaç edinen görüşlere karşı yetişme ve gelişmelerini sağlayıcı tedbirler" ile korunması amaçlanır. Bu kontrol refleksinin yanında 1985 yılında öğrenciler için disiplin yönetmeliği yürürlüğe konularak "Yükseköğretim kurumu içinde siyasi faaliyetlerde bulunmak, yükseköğretim kurumu içinde bildiri dağıtmak, afiş ve pankart asmak" cezai sorumluluğa tabi tutulur(Doygun, 2018, s.64).

Darbeden birkaç yıl sonra, önce dergiler ardından da öğrenci dernekleri etrafında bir üniversite hareketi başlamıştır. $O$ dönemde, sosyalist hareketin hemen hemen her türlü rengini içinde barındıran ve yapı olarak toplumsal muhalefet tarzı ile benzeşen öğrenci hareketleri, darbenin yarattığı iklimden çıkma çabasında olan toplumsal muhalefet hareketinin önünde yer alır. Başlangıçta üniversitelerdeki çeşitli sosyalist gruplara yakın öğrencilerin, kamusal alanda baskının yoğun olarak yaşandığı o yıllarda 80 öncesi deneyimleri tekrar canlandırma anlamındaki teşebbüsleri önemli bir adımdır. Bu grupların çıkardığı gençlik der- 
gilerinin yaygınlaşmasının ardından öğrenci derneklerini kurma girişimleri başlar ve bu, hareketin başlıca mücadele alanı haline gelir. Büyük güçlüklerle kurulan bu derneklerde ortak platformlar oluşturularak kitlesel eylemler gerçekleştirilir. Ancak söz konusu derneklerin, çeşitli sol grupların ayrışma ve çekişme yaşadığı başlıca mekânlar haline gelmesi ve dünyadaki gelişmelerin yarattı̆̆ ideolojik iklim gibi nedenlerle 1989'a gelindiğinde dernekler kapatılır (Koçak, 2004, s.589-590). Diğer taraftan 1980 döneminde, bu dönemi önemli kılan ve teori ile pratikte toplumu etkileyen farklı bir oluşum söz konusudur. Kamusal alan bağlamında önemli veriler bulabileceğimiz bu dönemde, Çaha'ya göre (1998, s.93-94); adeta bir zihniyet dönüşümü yaşanarak o zamana değin cumhuriyet Türkiye'sinde baskıcı ve benzeştirici politikalarla görünmez hale gelen birçok sivil unsur gün yüzüne çıkmaya başlamıştır. 80 yılına kadar, mülkiyet ve üretimin büyük kısmını elinde tutan ve bu gücü farklı alanlarda kullanan devletçi zihniyet, 80'li yıllarda liberal düşünce ile karşı karşıya gelerek farklı bir sorgulama ve sorgulanma sürecine girmiştir. İç dinamiklere ek olarak küreselleşmenin oluşturduğu dış dinamiklerin tesiri ile liberal temalar geniş bir yaygınlık alanı bulurken özgürlük, insan hakları, adalet, minimal devlet, sinırlı devlet gibi kavramlar kamusal alanda farklı kesimlerin tartıştığı konular haline gelmiştir. Ayrıca etnik, mezhebi, siyasi, kültürel alanlarla birlikte cinsiyet alanında da hak talebini vurgulayan gruplar kamusal alanda görünmeye başlar. Diğer bir farklı nokta ise söz konusu grupların sistemle hesaplaşan söylemler yerine hak talep eden söylemler üretmesidir. Dolayısıyla 60'ları "hızla" etkileyen ideolojilerin artık hız kaybetmesi, mevcut ideolojilerin sorgulanmaya başlaması, önemli gelişmeler olarak bu dönemde yer bulmaktadır.

80 dönemi öğrenci hareketlerini analiz ederken diğer önemli bir vurgu örgütlenme biçimi ile ilgilidir. Darbe öncesi modeli üzerinden ilk etapta dernek tipi örgütlenmelerin geliştirilmesi başlıca hedef olmuş, buralar ayrica hem yasal hem de korsan eylemlerin organize edildiği mekânlar olarak kullanılmıştır. Bu dernekler resmi üyelerden çok aktivistlerle; birçok öğrenci için biçimsel demokrasi deneyimlerinin kazanıldığı, öğrenildiği yerlerdir. Dolayısıyla da darbenin, kamusal tartışma alanlarını boğduğu, demokratik ifade alanlarını kapattığı bir alanda demokratik özellikte bir karşıt alan açmada etkili olmuştur. Derneklerin, çoğunlukla 
sosyalist grupların etkisi ile sonlanmasının ardından kulüpler önem kazanır ancak kulüpler, kamusal bir tartışma alanı olmada derneklerden daha zayıf kalmış; daha çok sol kültürel değerlerin yayıldığı ve sosyalist öğrencilerin sosyalleşme imkânı buldukları yerler olmuşlardır. 80 sonrası dönemde öğrenci mücadelesi açısından ortaya çıan en önemli konu ise; darbenin üniversite alanındaki en önemli yansımalarından olan YÖK ve uygulamalarıdır. Bu duruma, birçok yürüyüş ve imza gibi eylemler düzenlenerek karşıt bir duruş sergilenmeye çalışılmıştır (Koçak, 2004, s.590-591). Bu noktada üniversite öğrencilerinin hem 68 kuşağına hem de dünyadaki öğrenci hareketlerine benzer bir şekilde, özerk üniversite isteği üzerinden muhalif olarak kendi hak taleplerine destek sağlama girişimlerinde bulunmuş ve gerçekleştirdikleri eylemlerle belirli bir kamuoyu oluşturmuşlardır.

80'lere genel olarak bakıldığında; süreci taşıyan toplumsal gelişmeler belli ki sahip olduğu potansiyel ile devamında; 90'lı yıllara gelindiğinde öğrenci hareketlerinde canlanma olmuştur. Belirtmek gerekirse 90 'lı yıllar; önemli tartışmaları 2000'lerden günümüze kadar taşıyan; örneğin 28 Şubat süreci, ya da kat sayı mağduriyeti gibi farklı somut problemlerin ortaya çıktığı bir dönemdir. Bir makale olarak bu çalışmanın sınırlarını oldukça genişletecek olan ve kendi iç dinamikleri açısından farklı bir çalışmada ele alınması gerektiğini düşündügümüz 90'lar ve sonrası öğrenci hareketlerine; tarihsellik üzere çok temel noktalar açısından değinilecektir. Bu çerçevede ele alındığında; özellikle 95 ve 96 yıllarında eylemler üniversitelerden meydanlara taşmış; talepler, yine öğrenci merkezli olmasına karşın, halk nezdinde de dikkatleri üzerine çekmiş ve kamuoyu oluşturmuştur. O ylllarda öğrencilerin eylem nedenlerinin başında 80 darbesiyle kurulan YÖK bulunmaktadır. Bunun yanı sıra öğrencilerin demokratik ve ekonomik talepleri de önemli bir yer edinmiştir. Derneklerin yasaklanması, eylemlerin kısıtlanması gibi artan baskılardan kurtulma ve 80 darbesinden beri süre gelen kamusal alandaki boğulmayı rahatlatma talepleriyle birlikte; harçların kaldırılması, ücretsiz eğitim gibi talepler aslında 80'lerin 90'lara bu alanda taşıdığı dinamiklerdir.

İfade etmek gerekirse 90'larda öğrenci hareketleri üç temel yap1 üzerine inşa edilmiştir. Bu üç yapıdan birisi "Öğrenci Koordinasyonu", diğeri "Öğrenci İnisiyatifleri”, bir diğeri ise "Öğrenci Platformu” dur. Bu 
yapılar, ayrı ayrı tartışmalara dahil olarak taleplerini duyuruyor; kimi zaman da bir araya gelerek tek bir çatı altında ortaya çıkabiliyorlardı. Akdeniz (2016), bu üç temel yapıyı şu şekilde özetlemektedir: “Öğrrenci Koordinasyonu; kendisini anti-faşist gençlik örgütü olarak ifade ediyordu. Kitlesel bir yapı olsalar da siyasal darlı̆̆ı aşamadılar. Örgütü antifaşist tanımlamaka, talepleri olan geniş kesimleri dişarda bıraktılar. (...) Öğrenci Insiyatifleri çeşitli üniversitelerde kol-kulüp ve topluluklarm ve kimi yerlerde öğrenci temsilcilerinin fiilen buluştuğu bir yapıydı. Bu oluşum talepleri için mücadele etmek isteyen her öğrenciye kapıyı açıyordu. Bir de Öğrenci Platformu vardı. Bu yapı da geriye kalan devrimci gençlik örgütlerinin birliği olarak kurulmuştu."

90'larda okul koridorları, duvarları ve kantin öğrencilerin iletişim ve kontrolü elde tutabilme mücadelesi için önemli alanlar olmuştur. Duvarlar; panolar, afişler, duvar yazıları için; koridorlar ve kantin, toplanarak sesli tebliğde bulunabilmek ya da tartışmaları var edebilmek için önem taşımaktadır. Bu durumu Koçak şu şekilde ifade etmektedir(2015, s. 746);"Sanırım duvarlar hiçbir alanda üniversitede olduğu kadar ve öğrenci hareketi için olduğu derecede önem taşımaz. Okullardaki öğrenci direnişinin sembolik hâkimiyetini, duvarlardaki malzemenin kalıcılı̆̆ı ve yaygınlığı belirleyebilmektedir. Polislere, okul idaresine; faşistlere, İslamcilara ve diğer sol gruplara karşı duvardaki afişin, panonun korunmasi, her etkinlikte okul duvarlarının bunlarla donatılması önemli bir hâkimiyet çabasıdır. Bu karşıt kamusallık varlığını üniversitede en önce duvarlarda duyurur, kantinlerdeki solcuların hemen seçilebilen 'rezervasyonlu masaları' ise kamusal tartışmalarn mayalandığı ya da alevlendiği yataklar olagelmişlerdir."

Tüm bunlarla birlikte 90'ların sonunda öğrenciler arasında örgütlenmenin gözden düşüşünün yaygınlaşması ve bireyselleşme konularını ele almamız gerekir. Ancak 90'lı yıllar için ikircikli bir durum söz konusudur. Bir yanda öğrenci kesimi örgütlenirken ve bu örgütlerin kamusal alanda söz sahibi olma mücadeleleri sürerken diğer yanda da yine bu kesim üzerine apolitizm tartışmaları yapılmaktadır. Bu yöndeki fikirlerin nedenlerinden birisi artan bireyselleşme olgusunun 90'l1 yıllarla beraber toplumsal ilişkilerde çok daha görünür hale gelmesi ile yakından ilgilidir. Lüküslüye göre (2015) 80 sonrasında başlayan ve her geçen gün öğrenciler

\footnotetext{
${ }^{5}$ https://www.evrensel.net/haber/295119/1990lardan-bugune-universite-mucadelesi-ve-yok (Erişim tarihi: 18.09.2018).
} 
arasında yaygınlaşan apolitizm ve depolitizasyon, 90'ların sonu ve 2000'li yılların başlarına gelindiğinde gözden kaçmayacak bir gerçekliğe kavuşmuştur. Fakat buradaki apolitikliği Lüküslü(2015, s.163); "aktif apolitizm" ${ }^{\prime}$ olarak tartışmaya açar. Çalışmasında değindiği araştırma verileri ise 90larda öğrenci hareketlerini önceki yılların çalkantılarının ne denli etkilediğini gözler önüne sermektedir. 1999 yılında yayımlanan Türkiye Gençliği 98: Suskun Kitle Büyüteç Altında ve 2003 yılında yayımlanan Türk Üniversite Gençlik Araştırması'nın verilerine göre, "gençlerin sadece \%3.7'si bir siyasal parti üyesidir. Siyasal partilerin dışında herhangi siyasal, sosyal veya kültürel dernek veya gruplara üye olanların oranı ise sadece \%3, arkadaşları ile aralarında siyasetten bahsedenlerin oranı ise sadece $\% 10^{\prime}$ dur ve gençlerin çoğunluğu hiçbir siyasal partinin gençlerin problemleri ile ilgilenmediğini düşünür. 2003 yılında üniversite gençleri üzerine yapılan araştırma da durumun üniversite öğrencileri arasında da pek farklı olmadığını gözler önüne serer. Örneğin, üniversite gençlerinin sadece \%1.4'ü boş zamanlarını derneklerde ve siyasal partilerde geçirmektedir. Dolayısıyla o yılları değerlendirdiğimizde; siyaseti konuşmaktan, düşünmekten ya da bu motivasyonla eyleme geçmekten geri duran bir neslin yetiştiği görülmektedir. Bu durum bizlere Sennett'in(2010) kamusal insanın çöküşü olarak ifade ettiği geç modern dönem kamusallığ1 olarak narsizm ve rehavet ilkelerini hatırlatırken, üniversite gençliğinin apolitizm tartışmaları ile birlikte; teslimiyetçi ve kanıksayıcı bir ruh haline bürünerek sadece siyasetten değil; hayatın anlamını sorgulama, ya da gelecek için özgeci bir ideali düşlemekten geri durma refleksine yönelik tartışmalara davet ediyor. Fakat yakın geçmişte farklı ve benzer bir politik duruşla oldukça aktif örnekler sergileyen üniversite gençliği temsillerini göz önünde bulundurduğumuzda bu davetkârlık, söz konusu dönem için görece tutarlı olsa da bugünü açıklamak için yeterli görünmüyor. Şüphesiz burada bahsedilenleri kısaca geçiştirmeden, daha fazla veri ile anlamaya ve açıklamaya ihtiyacımız var.

\footnotetext{
6 "Aktif apolitizmi Lüküslü(2015, s.163) çalışmasında şu şekilde aktarmaktadır: "tıpkı Kilise, diplomasi ve savunma gibi konularda örneği görüldüğü gibi kendini siyasetin dışında konumlandırma ve siyasetin üzerinde partizan bakış açıların uzağında geniş bir konsensüs sağlama çabası".
} 


\section{Sonuç Yerine: Geçek ve "Mit" Olarak 68 Kuşağının Ardından...}

Türkiye'deki öğrenci hareketlerine gerek sosyal bilimler literatürü gerekse gündelik hayattaki yansımaları açısından bakıldığında; 68 kuşağının özel bir yer ve anlam atfı ile 80 ve sonrasındaki hareketliliklere nazaran çok daha fazla popülaritesi olduğu, hatta 68'in neredeyse mite dönüştüğü görülmektedir. Açıkçası Budizm, anarşizm, komünizm gibi birçok düşünce akımının etkide bulunduğu 68 Kuşağı gençliğinin faaliyetleri, içinde bulunduğu atmosferin etkisi ile farklı bir yerde dururken demokratik çoğulculuğa dair fikirlerin oluşmasına katkısıyla sonraki örneklerini cesaretlendiren önemli bir role sahiptir. 68 Kuşağı olarak o dönemi yorumlayanların kendi ifadesinde de bu önem hissedilmektedir. Yorumlarda ise genellikle 68 kuşağı; bilgili, birikimli, aydın, politikayı bilen, liderlik vasıflarına sahip, eylemleri siyasi teorilere dayanan bir kuşak olarak tanımlanırken 80 ve sonrası hareketlerinde teorik boşluklar olduğu; 68'de yapı kurma söz konusuyken 80 ve sonrası için ise sadece direnişin olduğu gibi vurgular ön plana çıkmaktadır. Yine 68' deki hareketlerde sadece bireyin önemli olmadığı, siyasi bilincin ise toplumsal bilinçten kaynaklandığı; 80'lerde ise ağırlıklı olarak kadın hareketleri ve değişik ekonomik yapılanmalar bazında "bireyin toplumdaki yeri nedir?" sorusuna cevap arandığı ve sonrasındaki yıllarda bireyselleşmenin çok daha fazla görünür olmaya başladığı düşünülmektedir. Ayrıca zaman içerisinde toplumsal değerlere önem verilmesi ve otoriter kültürün daha çok benimsenmesiyle ilişkilerin sertleşip, 68'lerdeki özgürlükçü tavrının simgelerinin sonraki süreçte kültür emperyalizminin göstergeleri şeklinde algılanarak dışlandığı ifade edilmektedir. Dolayısıyla 68'in çiçek çocuklarının renkli görüntüsünün yerini kasketli, parkall, şayak pantolonlu ve kasvetli bir görüntü almış; 80 kuşağı kendisini gelenekten gelen bir otoritenin içinde bulmuştur. Diğer bir taraftan, 80'lilerin örgütlenme biçimi de değişmiş, 68'lerdeki gibi tabulaştırılmış doğal liderlerden beslenen dikey örgütlenmelerden ziyade 80'lerde artık bireysel iradenin lezzetlerine yönelik yatay örgütlenme biçimleri ortaya çımıştır ${ }^{7}$. Sonuç olarak $80^{\prime}$ ler çok ağır süreçlerin tecrübe edildiği, geleceğe dair düşlerin

\footnotetext{
${ }^{7}$ http://www.msqsu.edu.tr/data/doc/temel eqitim etkinlikler/22.rtf(Erisim tarihi: 07.09.2015) Çalıșma ile ilgili ayrıntılı bilgi için bkz. Caner Karavit, Akadeğilmi, Stüdyo Imge Yayıları, İstanbul, 2002.
} 
kaybolmaya başladığı, gelecekle ilgili tasarımların artık yapılamadığı zamanlar olarak dile gelir(Karavit, 2002).

Bu çalışmada konu edilen dönemlerdeki öğrenci hareketlerinin; iktidar yapısı, devlet politikaları ve askeri darbelerle türdeş bir görünüm sergileyen toplum görüntüsüne karşıt ve muhalif nitelikte kamusal alanlar inşa ettikleri; oluşturdukları kamuoyunun da etkisi ile önemli sonuçlara sebep oldukları görülmektedir. 68 kuşağı için ilginç bir nokta ise hareketin olduğu yıllardaki analizlerde, sempozyum bildirileri ya da akademik çalışmalarda; bu dönem öğrenci hareketlerinin siyasi örgütler ve siyasi ideolojiler ile ilgili ya da bağlantılı olmadığı, sadece öğrencilerin, öğrenci olmaları dolayısıyla talep ettikleri haklar bazında eylemde bulundukları söz konusu edilirken, sonrasında daha çok sol ideolojiyle efsaneleşen bir hareket olmasıdır. Bu yıllarda öğrenciler; NATO, ABD protestoları, üniversitelerde ve toplumda özgürlük gibi istemleriyle sol görüşe yakın duran, sonrasında da bu görüş çerçevesinde örgütleşen birçok eylemde bulunmuş olsalar da, hareketlerin başlangıç verileri; üniversite yönetimi, hocaların derse devamı, tavrı ve öğrencilerle ilişkileri ayrıca da istihdam sorunları gibi genç üniversite öğrencilerinin kendi iç problemleri çerçevesinde sorunları gösteriyor. Burada; "var olan sosyal problemleri ne çözecek, bunun için nasıl bir düzen ve ilişkiler gerekecek?" sorularının cevabı olarak; dikensiz gül bahçeleri vaat eden ideolojiler, gerçekliğin söylemle inşasında hikâyeye ruh kazandıran asıl imgelere dönüşüyor. Dolayısıyla 68 kuşağı üzerine söylem alanının daha çok sol siyasi görüş çerçevesinde şekillendiği gözlemliyoruz. 80'ler ise çok daha karmaşık, 68 ile cesaretlenen, belirli bir politik duruşu olan ancak mevcut koşullarda her açıdan marjinal, dolayısıyla umut verici olmanın ötesinde umut kırıcı sonuçlarla yüzleşildiği, çok daha farklı bir dönemi anlatıyor.

Dönemleri tecrübe edenlerin yorumları çerçevesinde, öncesinde ifade edildiği gibi 68 kuşağının kendinden sonraki tüm öğrenci hareketlerine kıyasla toplumsal, siyasal ve kültürel açıdan çok daha farklı ve etkili dinamiklere sahip olduğu sonucuna varıyoruz. Ancak söz konusu gençlik hareketlerini kendi aralarında keskin kıyaslarla değerlendirmenin ötesinde, özgül koşulları çerçevesinde onların iç ilişkilerini ve etkileşim alanlarını anlamlandırmak, bu hareketlerin potansiyellerini ortaya çıkararak tarihsel bir bakış açısıyla günümüze uzanan bağlantılarının daha görünür 
hale getirecek. Bu kuşakların bir kısmı bugün, günümüz gençliğinin ebeveyni konumunda. Toplumsal hafızadaki anlatılardan gündelik politik söylemlere kadar bahsedilen durumun; o kuşak ailelerin günümüz üniversite gençliğinin dünyaya bakışını şekillendiren ciddi bir etki alanı olduğu kanaatindeyiz. Ancak bu durumu tartışmaya açabilmek ve bu kanaati değerlendirebilmek için nicel ve nitel saha verilerine ihtiyacımız var. 


\section{EXTENDED ABSTRACT}

\section{Rethink The Framework of The Public Sphere on The Student Movement in 68 and 80 in Turkey}

Gamze Aksan

Selcuk University

The main focus of this study is to evaluate student movements in Turkey in the $60 \mathrm{~s}$ and $80 \mathrm{~s}$ on the basis of public space discussion. Although the study does not aim to deal with the subject in a broad framework including the 90s and beyond student movements in terms of quality and quantity, some issues concerning the historical characteristics of the 90 s were also discussed and some of the issues that were related to the following examples were discussed. In this study, firstly, the main concepts and processes related to public sphere are evaluated; basic theoretical approaches are discussed. Later on, some of the movements were tried to be interpreted through some studies and comments. As a result, in the center of the question is What remained of myth and reality from the 68 movements to the present? A brief evaluation of some discourses on university youth has been made.

When the student movement in Turkey should social science terms reflections on everyday life to stretch literature; It is seen that the generation of 68 has a much more popularity compared to the mobility of the 80's and beyond with a special reference to place and meaning, and even 68 is almost myth. Obviously, Buddhism plays an important role in encouraging the subsequent examples of the activities of youth of the generation, which are influenced by many currents of thought such as anarchism and communism, while contributing to the formation of ideas of democratic pluralism while standing in a different place with the influence of the atmosphere. This importance is felt in the expression of those who interpret the period as the generation of 68 . In the comments, generally 68 generations; it is defined as a generation that is knowledgeable, knowledgeable, enlightened, knows the politics, has leadership qualities, and whose actions are based on political theories, and that there are theoretical gaps in the activities of the 80's and beyond; In the case of building a building in 
68, the emphasis is on the foreground as in the 80's and beyond. Again in the movements of 68 , it is stated that not only the individual is important, but the political consciousness stems from social consciousness; In the 80s, it is thought that the answer to the question will be what is the place of the individual in society? India is mainly sought on the basis of women's movements and different economic structures, and in the following years, individualization is becoming more visible. In addition, it is stated that relations with the adoption of authoritarian culture become more rigorous and the symbols of libertarian attitude in the $68 \mathrm{~s}$ are perceived as signs of cultural imperialism in the subsequent period. Therefore, the colorful image of 68's flower children have been replaced by a gloomy, parka, shoestring pants and gloomy; The 80 generations found themselves in an authority from tradition. On the other hand, the form of organization of the 80 s has changed, as in the '70s, rather than the vertical organizations fed by tabooed natural leaders, horizontal forms of organization for the tastes of individual will have emerged in the 80s. As a result, the 80s experience very heavy processes, dreams of the future began to disappear, future related designs are expressed as times cannot be done anymore (Karavit, 2002).

In this study, the student movements in the periods; they have built public spaces opposing and opposing the image of society, which is homogeneous with the power structure, state policies and military coups; It is seen that they cause important results with the effect of the public opinion they create. An interesting point for the generation of 68 in the analysis of the movement, symposium papers or academic studies; it is said that the student movements are not related to or linked to political organizations and political ideologies, but that the students act on the basis of the rights they demand because they are students. In these years, learners; NATO, the US protests, freedom in universities and society, such as the demands of the leftwing view, and then organized in the framework of this view, although many actions, although the initial data of the movement; university administration shows the problems of young university students such as attendance, attitudes and relations with the students, as well as employment problems within the framework of their own internal problems. Here; What will solve existing social problems, and what kind of order and relations will be required for this? The ideologies promising 
thornless rose gardens turn into actual images that bring spirit to the story in the discourse construction of reality. Therefore, we observe that the discourse area on the 68 generations is mostly shaped within the framework of the left political view. The ' 80 s describe a much more complex period, encouraged by 68 , with a certain political stance, but in a current situation where marginal in all respects, and therefore more than hopeful, are faced with disappointing consequences.

Based on the comments of those who have experienced the periods, we conclude that the 68 generations, as stated before, have much more different and influential dynamics in social, political and cultural terms than any subsequent student movement. However, beyond evaluating these youth movements with sharp comparisons among themselves, understanding their internal relations and areas of interaction within the framework of their specific conditions will reveal the potential of these movements and make their connections from the historical perspective to the present day more visible. Some of these generations are the parents of today's youth. From the narratives in social memory to the daily political discourses; we believe that this generation of families is a serious field of influence that shapes the view of today's university youth to the world. However, we need quantitative and qualitative field data to discuss this situation and to evaluate this opinion.

\section{Kaynakça / References}

Akyüz, Y. (1969). “Fransa'da öğrenci hareketleri”. 1968 yılı öğrenci hareketleri (Dünyada Ve Türkiye'de) İçinde. Ankara: Ankara Üniversitesi Eğitim Fakültesi Yayınları, 120-133.

Arendt, H. (2018). İnsanlık durumu (9. Baskı). (Çeviren: Bahadır Sina Şener). İstanbul: İletişim Yayınları.

Bacık, G. (2005). Kamusal alan tanımı üzerine bir tartışma. (Yayına Hazırlayan: Lütfi Sunar). Sivil bir kamusal alan. İstanbul: Kaknüs Yayınları, 9-17.

Başer, M., Ö. (2001). Türkiye'de öğrenci hareketi: Dünü ve bugünü. Ürün Sosyalist Dergi 9, Eylül /Ekim 2001. http://www.urundergisi.com/makaleler.php?id=132. Adresinden 11.12. 2016 tarihinde erişilmiştir. 
Bilgir, M. T. (2015). Richard Sennett'in çalışmalarında toplumsallaşmanın bazı referans alanları ve modernlik. Selçuk Üniversitesi Edebiyat Fakültesi Dergisi, 34, 267-282.

Can, T. (1996). Yükseköğretimde öğrenci olayları. Eğitim Yönetimi, 4. https://dergipark.org.tr/download/article-file/108640 Adresinden 11.12. 2016 tarihinde erişilmiştir.

Çaha, Ö. (1998-1999). İdeolojik kamusalın sivil kamusala dönüşümü. Doğu Batı, 5, 81-103.

Çaha, Ö. (2003a). Aşkın devletten sivil topluma. İstanbul: Gendaş Kültür Yayınları.

Çaha, Ö. (2003b). Mahrem kamusal alan. Sivil Toplum Dergisi, 2, 79-88.

Çaha, Ö.(2006). Türk kadın hareketi: "Kadınsı" bir sivil toplumun imkânı?. Kadın Çalışmaları Dergisi, 1(3), 6-15.

Çetinkaya, H. (2002). 68'den 78'e sancılı yıllar kuşatılmış sokaklar. İstanbul: Günizi Yayıncilık.

Doygun, E. (2018). Sosyal hareketler "Ankara Üniversitesi, Odtü, Çankırı Karatekin Üniversitesi, Kırıkkale Üniversitesi örnekleri ile son on yılda Türkiye'de yaşanan öğrenci hareketleri. Yayımlanmamış Yüksek Lisans Tezi, Kırıkkale Üniversitesi Sosyal Bilimler Enstitüsü, Kırıkkale.

Erdoğan, M. (2006). Kamu alanı ve liberalizm: Birkaç not. Ahmet Karadağ (Ed.), Kamusal alan ve Türkiye. Ankara: Asil Yayın Dağıtım, 92-109.

Eroğlu, M. (2010). John Locke'un devlet teorisi. Akademik Bakış, 21, 1-15.

Erol, A. (2003). Bir kamusallık inşası olarak halk evleri. Sivil Toplum Dergisi, (2), 59-69.

Eskicumalı, A. (2003). Eğitim ve toplumsal değişme: Türkiye'nin değişim sürecinde eğitimin rolü. Boğaziçi Üniversitesi Ĕ̆itim Dergisi, 19(2), 15-30.

Evrensel Gazete . (2016). 1990'lardan Bugüne Üniversite Mücadelesi Ve Yök. https://www.evrensel.net/haber/295119/1990lardan-bugune-universite-mucadelesi-ve-yok , adresinden 20.01.2019 tarihinde erişilmiştir.

Fraser, N. (2015). Kamusal alanı yeniden düşünmek: Gerçekte var olan demokrasinin eleştirisine bir katkı. (Ed: Meral Özbek). Kamusal Alan. İstanbul: Hil Yayınları, 103-132.

Göğüş, M. (1969). Amerikan üniversitelerindeki öğrenci hareketlerinin mahiyet ve nedenleri. 1968 Yalı Öğrenci Hareketleri (Dünyada Ve Türkiye'de) İçinde. Ankara: Ankara Üniversitesi Eğitim Fakültesi Yayınları. 
Göle, N. (2003). Kamusal alan ve sivil toplum üzerine. Sivil Toplum Dergisi,(2), 89-99.

Gönenç, C. (1988). 80 Sonrası Öğrenci Hareketine İlişkin Bazı Notlar. https://www.gelenek.org/80-sonrasi-ogrenci-hareketine-iliskin-bazinotlar, adresinden 20.02.2019 tarihinde erişilmiştir.

Habermas, J. (2004). Kamusal alan. (Ed: Meral Özbek). İstanbul: Hil Yayınları.

Habermas, J. (2007). Kamusallığın yapısal dönüşümü. (Çev: Tanıl Bora, Mithat Sancar). İstanbul: İletişim Yayınları.

Hansen, M. (2015). Yirmi yılın ardından Negt ve Kluge'nin 'kamusal alan ve tecrübe'si: değişen karışımlar ve genişlemiş alanlar. (Ed: Meral Özbek). Kamusal Alan. İstanbul: Hil Yayınları, 141-176.

Hayek, F. A. (1999). Kölelik yolu, Çev: Turhan Feyzioğlu, Ankara: Liberte.

Hayek, F.A. (1995). Kanun, yasama ve özgürlük: Sosyal adalet serabı. Çev: Mustafa Erdoğan, Ankara: Türkiye İş Bankası Yayınları.

Karadağ, A.(2003). Kamusal alan modelleri: Çoğulcu perspektiften bir değerlendirme. Ankara Üniversitesi Sbf Dergisi, 58 (3), 172-195.

Karavit, C.(2002). Akadeğilmi. İstanbul: Stüdyo İmge Yayıları.

Kocatürk, U. (1999). Cumhuriyetin anlamı önemi ve milletimize kazandırdıkları. Hacettepe Üniversitesi Edebiyat Dergisi, Cumhuriyetin 75. Yıl Özel Sayısı.

Koçak, H. (2015). Karşıt bir kamusal alan olarak 80'ler sonrası öğrenci hareketleri. (Ed: Meral Özbek). Kamusal Alan. (2004 İlk Baskı). İstanbul: Hil Yayınları.

Konanç, E. (1969). İtalya'da öğrenci hareketleri. 1968 Yılı Öğrenci Hareketleri (Dünyada Ve Türkiye'de). Ankara: Ankara Üniversitesi Eğitim Fakültesi Yayınları.

Lüküslü, D.(2015a). Türkiye'de "Gençlik Miti" 1980 sonrası Türkiye gençliği (4. Bask1). İstanbul: İletişim Yayınları.

Lüküslü, D.(2015b). Türkiye'nin 68'i: Bir kuşağın sosyolojik analizi. Ankara: Dipnot Yayınları.

Negt, O. ve Kluge, A. (2004). Kamusal alan ve tecrube'ye giriş, Ed: Meral Özbek. Kamusal Alan. İstanbul: Hil Yayınları, 133-141.

Negt, O. ve Kluge, A. (2018). Kamusallık ve tecrübe, burjuva ve proleter kamusallığın analizine doğru. Çev. Müge Atala, Nota Bene Yayınları, İstanbul.

Olgun Biçer, H. (2017). Jurgen Habermas, Hannah Arendt ve Richard Sennett'in kamusal alan yaklaşımları. Sosyolojik Düşün, 2(1). 45-54. 
Onat, N. (2013). Kamusal alan ve sinırları: Hannah Arendt Ve Jürgen Habermas'ın yaklaşımları. İstanbul: Durakistanbul Yayınları.

Özbek, M. (2004). Kamusal alanın sınırları. (Ed: Meral Özbek). Kamusal alan. İstanbul: Hil Yayınları.

San, C. (1969). Almanya'da öğrenci hareketleri. 1968 yılı öğrenci hareketleri (Dünyada Ve Türkiye'de) İçinde. Ankara: Ankara Üniversitesi Eğitim Fakültesi Yayınları.

Sand1kçıŏ̆lu, İ.(1969). Amerika'da öğrenci hareketleri. 1968 yılı öğrenci hareketleri (Dünyada Ve Türkiye'de) İçinde. Ankara: Ankara Üniversitesi Eğitim Fakültesi Yayınları.

Sarıbay, A. Y. (2000). Kamusal alan diyalojik demokrasi sivil itiraz. İstanbul: Alfa Yayınları.

Sennet, R. (1996). Kamusal insanın çöküşü. (Çev: S. Durak Ve A. Yılmaz). İstanbul: Ayrintı Yayınları.

Tezcan, M. (1969). Türkiye'de öğrenci hareketleri. 1968 yılı öğrenci hareketleri (Dünyada Ve Türkiye'de) İçinde. Ankara: Ankara Üniversitesi Eğitim Fakültesi Yayınları.

Toprak, Z. (2018). 1968-1969 İstanbul üniversitesi boykot ve işgalleri. Toplumsal Tarih, 293('68 Özel Sayıs1), 72-82.

Türk Dil Kurumu (Tdk). Güncel Türkçe sözlük. http://www.tdk.gov.tr/index.php?option=com_gts\&view=gts, Erişim Tarihi: 10.02.2019.

\section{Kaynakça Bilgisi / Citation Information}

Aksan, G. (2019). Kamusal alan kavramı çerçevesinde Türkiye'de 68 ve 80'lerdeki öğrenci hareketleri üzerine yeniden düşünmek. OPUSUluslararası Toplum Araştırmaları Merkezi, 13(19), 2768-2803. DOI: 10.26466/opus.604812 